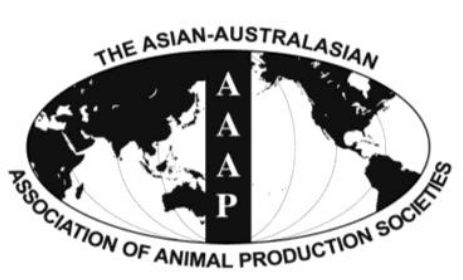

Open Access

Asian Australas. J. Anim. Sci.

Vol. 28, No. 9 : 1309-1316 September 2015

http://dx.doi.org/10.5713/ajas.15.0021

www.ajas.info

pISSN 1011-2367 elSSN 1976-5517

\title{
Carcass Composition and Cuts of Bulls and Steers Fed with Three Concentrate Levels in the Diets
}

\author{
Ivanor Nunes do Prado*, Rodrigo Augusto Cortêz Passetti, Dayane Cristina Rivaroli, Mariana Garcia Ornaghi, \\ Kennyson Alves de Souza, Camila Barbosa Carvalho ${ }^{1}$, Daniel Perotto ${ }^{2}$, and José Luiz Moletta ${ }^{2}$ \\ Department of Animal Science, State University of Maringá, Maringá, PR 87020-900, Brazil
}

\begin{abstract}
In this paper, weight, carcass dressing, weights of the primary cuts, weights of the physical components of the primary cuts, and weights of the main commercial cuts of 66 Purunã animals, of which 33 were bulls and 33 were steers were evaluated. These animals, with an average age of 19 months at the beginning of the experiment, were finished in a feedlot system during 116 days, and were fed with diets containing three levels of concentrate $(0.8 \%, 1.1 \%$, and $1.4 \%$ of body weight). The concentrate was formulated with $25 \%$ soybean meal, $73 \%$ ground corn grain, $1 \%$ of a mineral mix, and $1 \%$ of limestone. The interaction between sexual groups and the concentrate level was not significant for any of the variables. Likewise, no effect of the concentrate level was detected on the same variable traits. The bulls demonstrated higher hot carcass weights $(265.1 \mathrm{vs} 221.7 \mathrm{~kg}$ ) and a higher proportion of forequarter (38.4\% vs $36.1 \%$ ) however the steers presented with higher proportions of side (19.7\% vs $18.5 \%)$ and hindquarter (44.2\% vs $43.1 \%)$. The bulls produced higher yields of muscle in the three primary cuts, there by resulting in higher yields of edible portions of the carcass. The bulls also produced higher weights of tenderloin, knuckle, topside, flat, eye round, rump, and rump cover. The finishing of young bulls in feedlot is to be recommended, since the animals produce carcasses with higher amounts of edible meat and higher yields of commercial cuts, thus allowing for a better price for the carcass. Low concentrate level could be used due to the lower cost of production for farmers. (Key Words: Concentrate Level, Edible Portion, Meat Production, Sexual Groups)
\end{abstract}

\section{INTRODUCTION}

There are three principal beef producers and exporters around the world: Brazil, United States, and Australia (ANUALPEC, 2014). In these countries, the cattle carcasses are dissected and manufactured in wholesaler markets, according to the international or local standards, and depending on whether the destination of the products is for domestic trade or international markets. With globalization of the red meat industry, the standardization of the cuts and a service that facilitates the comparison and

\footnotetext{
* Corresponding Author: Ivanor Nunes do Prado. Tel: +55-02144-3011-8931, Fax: +55-021-44-3011-8931, E-mail: inprado@ uem.br

${ }^{1}$ Department of Food Science, State University of Maringá, Maringá, PR 87020-900, Brazil.

${ }^{2}$ Department of Animal Science, Agronomic Institute of Paraná, Ponta Grossa, PR 84001-970, Brazil.

Submitted Jan. 8, 2015; Revised Mar. 5, 2015; Accepted Apr. 10, 2015
}

commercialization between the different markets it is necessary (Shimada et al., 2004; Hocquette et al., 2012).

The Brazilian cattle primary cuts are the forequarter with five ribs, the side, and the hindquarter. Economically, a higher dressing of the hindquarter in relation to the other cuts is desired, because on this cut, the best parts with a high commercial value were found (Macedo et al., 2008; Perotto et al., 2009). In commercialized systems in Brazil, the carcass quarters are separated into approximately 20 commercial cuts with high variation in regional names. A cattle carcass with high quality and high dressing demonstrates an adequate relation between the component parts, maximum muscle, minimum bone, and adequate fat to secure a product with minimal handling and maximum palatability (Rotta et al., 2009a ; Maggioni et al., 2010). The industry and wholesalers desire, in the market, carcasses that allow for a more adequate utilization.

When comparing the dressing of primary cuts in the different animals, some precautions should be taken; several 
times, the division of cuts were realized subjectively, there by leading to changes in results such as in the limits of side and hindquarter cuts, which vary according to the animal size and its adjustments and which can lead to variations in the cut dressings when they are inadequate (Nerín et al., 2006). Another use of the carcass dressing is to express the ratio between the carcass and animal weight. According to Macedo et al. (2008), the dressing estimate should be used together with the primary cuts to complement the evaluation of animal performance during development because the value of the carcass dressing is influenced by the animal live weight; this in turn is modified by the content of the gastrointestinal tract, the genetic group, and the animal's level of maturity (Missio et al., 2009). The feeding system and the diet composition can influence cattle carcass and meat characteristics (Rotta et al., 2009b). The physiological groups have a strong influence on growth, composition and distribution of carcass tissues (Aricetti et al., 2008; Prado et al., 2009). The physiological effect can be evidenced through the fattening process, as heifers reach the finishing phase before steers, who in turn reach the finishing phase before bulls (Rotta et al., 2009b). The fat accumulation in the carcass of bulls is lower than steers (Prado et al., 2009). The use of bulls promotes a higher slaughter age, and consequently, a higher hot and cold carcass weight, there by resulting in carcasses with higher rib-eye area (Aricetti et al., 2008; Prado et al., 2009). In relation to the commercial cuts, bulls demonstrate a minor carcass proportion of hindquarters and a higher proportion of forequarters, leading to greater values in the carcass characteristics.

The practice of slaughter castrated animals is traditionally performed for economic reasons and customer acceptance (Bretschneider, 2005). Several slaughterhouses require animal castrated, justifying that this procedure favors the uniformity and quality of the carcass, and thus favors conservation and different aspects of the meat (Knight et al., 2000; Mach et al., 2009). In general, the performance results indicate that bulls grow faster, use food more efficiently, and produce carcasses with higher commercial meat percentages and less fat (Field, 1971; Prado et al., 2009). On the other hand, steers produce carcasses with more tender meat. Despite all of the knowledge on the effects of castration, the technique is still a subject of studies, because it maybe that the results are affected by other factors of the finishing system and feeding management. The objective of this paper was evaluate the carcass physical characteristics and the primary cuts of bulls and steers that were finished in a feedlot system and fed with diets containing three concentrate levels.

\section{MATERIALS AND METHODS}

The current experiment, approved by the Department of Animal Production of the State University of Maringá (CIOMS/OMS, 1985), was conducted at the Experimental Station of the Model Farm of the Agronomic Institute of Paraná (IAPAR) in Ponta Grossa, Paraná, South Brazil.

Sixty-six Purunã animals (1/4Aberdeen Angus $+1 / 4$ Caracu $+1 / 4$ Charolais $+1 / 4$ Canchim) were used in a factorial arrangement. The animals were weighed and distributed into two sexual groups (bulls $=33$; steers $=33$ ) and three diet groups $(0.8 \%, 1.1 \%$, and $1.4 \%$ of concentrate levels). The animals were selected at random and castrated at 210 days of age by standard surgical method, as described by Henricks (1991). The animals were castrated at 7 months of age with a standard scalpel instrument. All castrations were performed under local anaesthesia and analgesia (2\% lidocaine, [Xilocaina Ovejero, Laboratorios Ovejero, Spain] followed by a non-steroidal anti-inflammatory [Flunixin Meglumine, Laboratorios Karizoo S.A., Spain]). The animals were allocated into individual pens and kept in a feedlot system for 116 days. The animals were fed twice a day (8:00 and 16:00 hours) with a diet containing corn silage and concentrate in separate troughs (Table 1). Concentrate quantity was adjusted every 28 days when the animals were weighed after a 16-hour fasting period. The concentrate and corn silage intake were recorded daily until day 116 of the experimental period for $1.5 \mathrm{~kg}$ per day

Table 1. Chemical composition of ingredients in diets (\% on dry matter)

\begin{tabular}{lcccc}
\hline \multirow{2}{*}{ Item } & \multicolumn{3}{c}{ Ingredients } \\
\cline { 2 - 5 } & Soybean meal & Corn grain & Corn silage & Concentrate \\
\hline Organic matter & 93.62 & 96.64 & 97.87 & 95.45 \\
Ashes & 6.38 & 2.70 & 5.02 & 4.38 \\
Crude protein & 49.1 & 8.93 & 5.66 & 16.0 \\
Ether extract & 1.30 & 3.36 & 2.13 & 1.41 \\
Total carbohydrates & 43.0 & 86.8 & 89.1 & 77.1 \\
Neutral detergent fiber & 6.00 & 17.9 & 43.5 & 18.2 \\
Acid detergent fiber & 13.1 & 4.40 & 26.8 & 5.92 \\
Non fibrous carbohydrates & 37.0 & 68.9 & 45.6 & 58.9 \\
Total digestible nutrients & 82.2 & 80.8 & 60.5 & 78.8 \\
\hline Dab
\end{tabular}

Data obtained from the Laboratory of Food Analysis, Instituto de Pesquisa Agropecuária do Paraná. 
according to NRC (2000). The water, concentrate and corn silage were distributed ad libitum in separately drinkers and feeders.

Dry matter content of the ingredients (silage and concentrate mix) was determined by oven-drying at $105^{\circ} \mathrm{C}$ for $5 \mathrm{~h}$, following ([AOAC, 2005]) - method 930.15). Organic matter content was calculated as the difference between dry matter and ash contents, with ash determined by combustion at $550^{\circ} \mathrm{C}$ for $5 \mathrm{~h}$. Nitrogen content was determined by the Kjeldahl method ([AOAC, 2005] Method 976.05). The heat stable alpha-amylase was utilized to determined neutral detergent fiber (NDF) and acid detergent fiber (Mertens, 2002). Total carbohydrates (TC) were obtained by the following equation: TC $=100-(\%$ crude protein $+\%$ ether extract+\% ash). (Sniffen et al., 1992). Non-fiber carbohydrates were determined as the difference between TC and NDF. Total digestible nutrient (TDN) content of the diets was obtained by methodology described by Kearl (1982). The samples were analyzed at the Laboratory of Food Analysis, IAPAR.

Animals were weighed once at the beginning of the experiment and then once every 28 days (after fasting from solid food for a period of 16 hours). Daily feed intake was estimated as the difference between supplied feed and refusals in the trough. During the collection period, samples of the supplied feed and refusals were collected, and a representative composite sample was drafted per animal in each treatment for further analyses.

After reaching the final body weight ( 23 months), the animals were transported to the slaughterhouse. The animals were slaughtered at a commercial slaughterhouse. The animals were stunned using a captive-bolt pistol and dressed according to commercial practices in Brazil. No electrical stimulation of carcasses was performed. Carcasses were identified, weighed (hot carcass weight), and chilled for 24 hours at $4^{\circ} \mathrm{C}$. After chilling, the right half of the carcass was used to determine the carcass quantitative and the physical characteristics. The cold left half of the carcasses were separated into the following primary cuts: hindquarter, which was comprehend of the posterior part of the carcass, separated from the forequarter between the fifth and sixth rib and the side at an approximate distance of 20 $\mathrm{cm}$ from the vertebral column; forequarter, which was composed of the neck, shoulder, foreleg arm, and five ribs, and side, which was composed of the region of the sixth rib and the abdominal muscles, as showed in Figure 1.

The cuts were weighed individually, and its proportions were determined in relation to the appropriate half of the cold carcass. Afterwards, the secondary cuts were obtained according to the Brazilian classification of beef cuts, in which the forequarters were separated into their cuts (shoulder, chuck tender, heart, chuck, neck, and muscle)
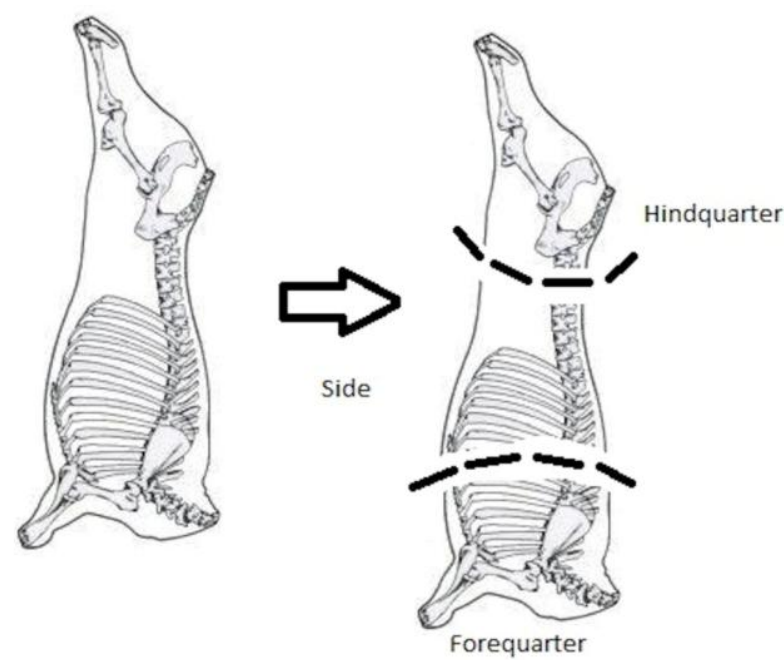

Figure 1. Primary carcass cuts.

and the hindquarters were separated into their cuts (tenderloin, strip loin, rump, rump cover, topside, flat, knuckle eye round, and muscle). Also, bone from these components was weighed. The calculations of primary and second cuts percentage were obtained by the sum between those cuts.

To determinate the carcass physical composition in terms of muscle, fat, and bone, a piece corresponding to the $10-11-12^{\text {th }}$ rib was incised, according to Hankins and Howe (1946).

The variables were submitted to the normality test by the UNIVARIATE (SAS, 2004) procedure. The variable whose hypothesis had a normal distribution accepted by the Shapiro-Wilk test at a 5\% confidence level, was analyzed by the minimum square methodology general linear model (SAS, 2004). Characteristics whose hypotheses were not accepted by the normal distribution were transformed by the square root method according to the formula below:

$$
Y^{\prime}=\sqrt{Y}
$$

Where, $Y^{\prime}=$ variable value in the transformed scale, transformed by the square root. Next, the transformed variables were submitted to the normality test through the UNIVARIATE procedure (SAS, 2004). The variables in the transformed scale that presented with a normal distribution at a 5\% confidence level according to the Shapiro-Wilk test were analyzed by the minimum square methods (SAS, 2004). The characteristics for which normal distribution was not restored by the square root transformation were analyzed by the generalized linear models (Nelder and Wedderburn, 1972) by the GENMOD procedure (SAS, 2004). To present the results and for the purpose of discussion, the variable means transformed by the square root or analyzed by the general linear models were 
Table 2. Nutrients intake (dry matter basis) by cattle of different sexual groups (SG) and fed on three concentrate levels (CL) in the diets

\begin{tabular}{|c|c|c|c|c|c|c|c|}
\hline \multirow{2}{*}{ Intake } & \multicolumn{2}{|c|}{ Sexual groups } & \multicolumn{3}{|c|}{ Concentrate levels (\%) } & \multicolumn{2}{|c|}{$\mathrm{p}<$ value } \\
\hline & Bulls & Steers & 0.8 & 1.1 & 1.4 & SG & $\mathrm{CL}$ \\
\hline Silage intake (kg) & 4.79 & 4.73 & $5.05^{\mathrm{a}}$ & $4.78^{\mathrm{b}}$ & $4.45^{\mathrm{c}}$ & 0.75 & 0.05 \\
\hline Concentrate intake (kg) & 3.57 & 3.30 & $2.58^{\mathrm{a}}$ & $3.60^{\mathrm{b}}$ & $4.26^{\mathrm{c}}$ & 0.16 & 0.01 \\
\hline Total dry matter intake $(\mathrm{kg})$ & 8.44 & 8.12 & $7.69^{\mathrm{a}}$ & $8.41^{\mathrm{b}}$ & $8.78^{\mathrm{c}}$ & 0.25 & 0.01 \\
\hline Silage: concentrate ratio & 57.2 & 58.6 & $65.9^{\mathrm{a}}$ & $56.9^{\mathrm{b}}$ & $50.8^{\mathrm{c}}$ & 0.19 & 0.01 \\
\hline Organic matter (kg) & 8.20 & 7.89 & $7.45^{\mathrm{c}}$ & $8.17^{\mathrm{b}}$ & $8.54^{\mathrm{a}}$ & 0.25 & 0.01 \\
\hline Crude protein $(\mathrm{kg})$ & 0.85 & 0.81 & $0.70^{c}$ & $0.85^{\mathrm{b}}$ & $0.94^{\mathrm{a}}$ & 0.11 & 0.01 \\
\hline Neutral detergent fiber $(\mathrm{kg})$ & 2.78 & 2.72 & 2.71 & 2.77 & 2.77 & 0.49 & 0.84 \\
\hline Acid detergent fiber (kg) & 1.52 & 1.49 & 1.53 & 1.51 & 1.48 & 0.60 & 0.76 \\
\hline Ether extract (kg) & 0.12 & 0.11 & 0.11 & 0.12 & 0.12 & 0.60 & 0.73 \\
\hline Total carbohydrates (kg) & 7.08 & 6.83 & $6.52^{\mathrm{c}}$ & $7.06^{\mathrm{b}}$ & $7.31^{\mathrm{a}}$ & 0.28 & 0.01 \\
\hline Total digestible nutrient $(\mathrm{kg})$ & 5.76 & 5.52 & $5.11^{\mathrm{c}}$ & $5.75^{\mathrm{b}}$ & $6.09^{\mathrm{a}}$ & 0.19 & 0.01 \\
\hline
\end{tabular}

Means followed by different letters in the same row are different.

converted to the original scale; this was achieved by elevating the values to square, or taking the antilogarithm, respectively.

\section{RESULTS AND DISCUSSION}

No interactions $(p>0.05)$ were found between the sexual groups and the concentrate levels in the diet. Thus, the results were presented and discussed independently.

No difference was found on the variables for the sexual groups (Table 2). However, for the animals fed with three concentrate levels, as expected the animals fed with higher concentrate levels presented a higher concentrate intake and consequently a higher total dry matter intake. Thus, with the increase of concentrate in the diets the organic matter and crude protein also increased, but no differences were found on the fiber and ether extract content among the three diets. As a result, the diets with higher concentrate presented a higher content of TC and TDNs.
The slaughter weights were higher $(\mathrm{p}<0.001)$ for bulls than for steers (Table 3 ). This higher slaughter weight also resulted in higher hot carcass, forequarter, hindquarter and side weights for bulls. Also, when expressed as a carcass percentage, the forequarter was higher $(\mathrm{p}<0.001)$ for bulls than for steers. At contrary, the steers presented higher $(p<0.01)$ hindquarter and side percentages than bulls. Considering that the best commercial cuts are in the hindquarter, the steers are preferred in comparison for bulls.

According to Restle et al. (1999); Seideman et al. (1982) the hormone that is responsible for the characteristics related to sexual dimorphism and that leads to changes in different aspects of the carcass, such as the increase in the percentage values of the forequarters, is testosterone. This hormone has an effect reflex in the commercial aspect of the carcass because, cuts allocated in the forequarters have less value than in the hindquarters. According to Albertí et al. (2008), Arboitte et al. (2012), Freitas et al. (2008) the desired carcass has a higher

Table 3. Mean of the carcass characteristics according to the sexual groups (SG) and the concentrate level (CL) in the diet

\begin{tabular}{|c|c|c|c|c|c|c|c|}
\hline \multirow{2}{*}{ Characteristics } & \multicolumn{2}{|c|}{ Sexual groups } & \multicolumn{3}{|c|}{ Concentrate level (\%) } & \multicolumn{2}{|c|}{$\mathrm{p}<$ value } \\
\hline & Bull & Steer & 0.8 & 1.1 & 1.4 & SG & $\mathrm{CL}$ \\
\hline Initial weight (kg) & 337.71 & 310.42 & $330.53^{\mathrm{a}}$ & $329.39^{\mathrm{a}}$ & $312.28^{\mathrm{b}}$ & $* * *$ & $* * *$ \\
\hline Weight slaughter $(\mathrm{kg})$ & 493.51 & 443.01 & $449.52^{b}$ & $491.01^{\mathrm{a}}$ & $464.22^{\mathrm{b}}$ & $* * *$ & $*$ \\
\hline Average daily gain $(\mathrm{kg})$ & 1.34 & 1.14 & $1.02^{\mathrm{b}}$ & $1.39^{\mathrm{a}}$ & $1.31^{\mathrm{a}}$ & $* * *$ & $*$ \\
\hline Feed conversion ${ }^{1}$ & 6.30 & 7.12 & $7.54^{\mathrm{a}}$ & $6.05^{\mathrm{c}}$ & $6.70^{\mathrm{b}}$ & $* *$ & $* * *$ \\
\hline Carcass weight (kg) & 265.12 & 221.68 & $226.14^{\mathrm{b}}$ & $255.58^{\mathrm{a}}$ & $246.18^{b}$ & $* * *$ & $*$ \\
\hline Carcass dressing $(\%)$ & 53.72 & 50.04 & 50.30 & 52.05 & 53.03 & $* * *$ & Ns \\
\hline Forequarter (kg) & 51.01 & 40.02 & $41.92^{\mathrm{c}}$ & $48.45^{\mathrm{a}}$ & $45.33^{\mathrm{b}}$ & $* * *$ & $* *$ \\
\hline Hindquarter (kg) & 56.82 & 48.91 & $49.43^{c}$ & $55.41^{\mathrm{a}}$ & $53.54^{\mathrm{b}}$ & $* * *$ & $*$ \\
\hline Side (kg) & 24.73 & 21.91 & 21.72 & 23.93 & 24.22 & $* * *$ & NS \\
\hline Forequarter $(\%)$ & 38.42 & 36.11 & 37.10 & 37.82 & 36.82 & $* * *$ & NS \\
\hline Hindquarter $(\%)$ & 43.11 & 44.21 & 43.92 & 43.52 & 43.51 & $* *$ & NS \\
\hline Side $(\%)$ & 18.51 & 19.70 & 19.11 & 18.62 & 19.63 & $* *$ & NS \\
\hline
\end{tabular}

NS, not significant.

${ }^{1} \mathrm{~kg}$ dry matter feed intake/kg average daily gain.

Means followed by different letters in the same line are different. $* \mathrm{p}<0.05, * * \mathrm{p}<0.01, * * * \mathrm{p}<0.001$. 
proportion of the hindquarter (48\%), a maximum of $38 \%$ for the forequarter, and $14 \%$ for the side. In this study, only the steers produced a forequarter and hindquarter proportion inside the observed standards. However, bulls presented different values because of the higher forequarter development.

Weight at slaughter was higher $(\mathrm{p}<0.001)$ for animals fed with $1.1 \%$ concentrate levels in the diet and similar ( $>0.05$ ) for animals fed with $0.8 \%$ and $1.4 \%$ concentrate in the diets (Table 3). As observed for weight at slaughter, hot carcass, forequarter, hindquarter and side weights were higher $(\mathrm{p}<0.05)$ for animals fed with $1.1 \%$ of concentrate and similar for animals fed with $0.8 \%$ and $1.4 \%$ of concentrate. The increase of concentrate level in the diet resulted on better animal performance as can be seen on Table 3 where the average daily gain was lower for animals fed with $0.8 \%$ of concentrate but similar between animals fed with $1.1 \%$ and $1.4 \%$ of concentrate. The higher weight at slaughter, hot carcass, forequarter, hindquarter and side weights for animals fed with $1.1 \%$ can be explained because animals fed with $1.4 \%$ of concentrate had a initial lower weight $(\mathrm{p}<0.05)$. However, dressing carcass was similar ( $>0.05)$ for animals fed with three different concentrate levels. When expressed in percentage, the concentrate levels did not affect forequarter, hindquarter and side cuts of bulls.

Bulls presented a higher quantity of total edible proportion in the forequarter, hindquarter and side cuts (Table 4). However, the bone quantity was similar ( $>0.05$ ) between bulls and steers in the forequarter, hindquarter and side cuts. The results observed for the total dissection of the half carcass, reveal that bulls presented a higher $(\mathrm{p}<0.001)$ carcass edible portion (115.5 vs $92.8 \mathrm{~kg}$ ) and total bone quantity in the carcass $(21.5 \mathrm{vs} 18.8 \mathrm{~kg})$ than steers. The observation of carcass edible portion and bone quantity was also reported by Kuss et al. (2009), who stated that growing animals and bulls such as those in this study have an increase in muscle, which leads to greater demands in terms of the amount of support tissue. The forequarter, hindquarter and side cuts of bulls presented respectively $35.5 \%, 18.9 \%$, and $16.9 \%$ more edible portions than steers. Bulls demonstrated that they are more efficient in the total production of edible portions $(\mathrm{p}<0.001)$, as they produced $21.8 \%$ more. This superiority is attributed principally to a higher participation of the muscular tissue in carcasses of young bulls, which has also been observed by Kuss et al. (2009) and Restle et al. (2000).

When expressed in percentage, the forequarter of bulls contained a higher edible portion $(82.6 \%$ vs $80.5 \%$, $\mathrm{p}<0.001)$. Although it is only different by 2.6 percentage points, it should be taken into consideration that this category increased a total production of $35.9 \%$ more of edible portion only in the forequarter at the same age of steers. However, no differences $(p>0.05)$ were found in the percentage of edible portion between bulls and steers for the hindquarter $(85.3 \%$ vs $84.7 \%)$ and side cuts $(85.1 \%$ vs $84.2 \%)$. The superiority $(\mathrm{p}<0.01)$ of carcass edible portions (muscle+fat) of bulls $(84.3 \%)$ in relation to steers $(83.2 \%)$ is important to consider by the different segments of the beef chain; despite the fact that bulls produce carcasses with higher cut dressing with lower value, these animals produce more food. The wholesalers and retailers desire a carcass that allows for more adequate utilization. These would provide minor amounts of losses and higher percentages of

Table 4. Means at constituents of the forequarter, side, and hindquarters according to the sexual groups (SG) and the concentrate level (CL) in the diet

\begin{tabular}{|c|c|c|c|c|c|c|c|}
\hline \multirow{2}{*}{ Parameters } & \multicolumn{2}{|c|}{ Sexual groups } & \multicolumn{3}{|c|}{ Concentrate level (\%) } & \multicolumn{2}{|c|}{$\mathrm{p}<$ value } \\
\hline & Bull & Steer & 0.8 & 1.1 & 1.4 & SG & CL \\
\hline Forequarter edible portion $(\mathrm{kg})$ & 44.41 & 32.72 & 37.62 & 38.61 & 39.50 & $* * *$ & NS \\
\hline Hindquarter edible portion $(\mathrm{kg})$ & 49.73 & 41.84 & 45.3 & 46.4 & 45.7 & $* * *$ & NS \\
\hline Side edible portion (kg) & 21.42 & 18.32 & 19.81 & 20.00 & 19.84 & $* * *$ & NS \\
\hline Forequarter bone $(\mathrm{kg})$ & 9.13 & 7.87 & 8.46 & 8.56 & 8.47 & NS & NS \\
\hline Hindquarter bone $(\mathrm{kg})$ & 8.67 & 7.56 & 7.78 & 8.36 & 8.21 & NS & NS \\
\hline Side bone (kg) & 3.72 & 3.41 & 3.83 & 3.42 & 3.45 & NS & NS \\
\hline Carcass edible portion $(\mathrm{kg})$ & 115.56 & 92.88 & 102.73 & 105.01 & 105.04 & $* * *$ & NS \\
\hline Carcass bone (kg) & 21.52 & 18.84 & 20.07 & 20.34 & 20.13 & $* *$ & NS \\
\hline Forequarter edible portion (\%) & 82.61 & 80.52 & 81.53 & 81.22 & 82.00 & $* * *$ & NS \\
\hline Hindquarter edible portion (\%) & 85.32 & 84.72 & 85.41 & 84.84 & 84.84 & NS & NS \\
\hline Side edible portion $(\%)$ & 85.11 & 84.21 & 83.52 & 85.52 & 85.13 & NS & NS \\
\hline Carcass edible portion (\%) & 84.34 & 83.22 & 83.53 & 83.53 & 84.31 & $* *$ & NS \\
\hline Muscle (\%) & 67.33 & 62.91 & 65.04 & 65.51 & 64.80 & $* * *$ & NS \\
\hline Fat $(\%)$ & 18.22 & 22.52 & 20.61 & 19.52 & 20.91 & $* * *$ & NS \\
\hline Bone (\%) & 15.11 & 15.44 & 15.44 & 15.44 & 15.01 & NS & NS \\
\hline
\end{tabular}

NS, not significant.

Means followed by different letters in the same line are different. $* \mathrm{p}<0.05$, ** $\mathrm{p}<0.01, * * * \mathrm{p}<0.001$. 
Table 5. Means for the commercial cuts of the forequarter according to the sexual groups (SG) and the concentrate level (CL) in the diet

\begin{tabular}{|c|c|c|c|c|c|c|c|}
\hline \multirow{2}{*}{ Parameters } & \multicolumn{2}{|c|}{ Sexual groups } & \multicolumn{3}{|c|}{ Concentrate level (\%) } & \multicolumn{2}{|c|}{$\mathrm{p}<$ value } \\
\hline & Bull & Steer & 0.8 & 1.1 & 1.4 & SG & $\mathrm{CL}$ \\
\hline Shoulder (kg) & 4.06 & 3.55 & 4.18 & 3.59 & 3.64 & NS & NS \\
\hline Chuck tender $(\mathrm{kg})$ & 1.45 & 1.22 & $1.10^{\mathrm{c}}$ & $1.52^{\mathrm{a}}$ & $1.39^{\mathrm{b}}$ & $*$ & $* *$ \\
\hline Heart $(\mathrm{kg})$ & 6.34 & 5.18 & $5.11^{\mathrm{c}}$ & $6.34^{\mathrm{a}}$ & $5.80^{\mathrm{b}}$ & $* *$ & $*$ \\
\hline Muscle (kg) & 6.34 & 5.98 & 5.84 & 6.26 & 6.37 & NS & NS \\
\hline Neck (kg) & 11.77 & 7.53 & 8.68 & 9.97 & 9.64 & $* * *$ & NS \\
\hline Chuck (kg) & 6.00 & 3.94 & 4.33 & 5.30 & 5.15 & $* *$ & NS \\
\hline Shrink (kg) & 4.92 & 3.94 & 4.17 & 4.62 & 4.50 & $* *$ & NS \\
\hline Shoulder (\%) & 3.07 & 3.23 & 2.70 & 2.78 & 2.97 & NS & NS \\
\hline Chuck tender $(\%)$ & 1.09 & 1.09 & 0.97 & 1.13 & 1.13 & NS & NS \\
\hline Heart $(\%)$ & 4.76 & 4.68 & 4.51 & 4.94 & 4.71 & NS & NS \\
\hline Muscle (\%) & 4.87 & 5.47 & 5.25 & 5.01 & 5.26 & NS & NS \\
\hline $\operatorname{Neck}(\%)$ & 8.77 & 6.82 & 7.70 & 7.81 & 7.88 & $* * *$ & NS \\
\hline Chuck (\%) & 4.63 & 3.61 & 3.88 & 4.25 & 4.23 & $*$ & NS \\
\hline Shrink (\%) & 3.68 & 3.53 & 3.66 & 3.57 & 3.64 & NS & NS \\
\hline
\end{tabular}

NS, not significant.

Means followed by different letters in the same line are different. $* \mathrm{p}<0.05, * * \mathrm{p}<0.01, * * * * \mathrm{p}<0.001$.

pieces that allow, overall, cuts with the highest category and highest commercial value (Perotto et al., 2009).

The muscle percentage was higher $(\mathrm{p}<0.001)$ for bulls $(67.3 \%)$ than for steers $(62.9 \%)$. At contrary, the fat percentage was higher $(\mathrm{p}<0.001)$ for steers $(22.5 \%)$ than for bulls $(18.2 \%)$. However, the bone percentage was similar ( $p>0.001)$ between bulls $(15.1 \%)$ and steers $(15.4 \%)$. Castration alters the growth rate and carcass characteristics due to modifications of hormonal status (Lunstra et al., 1978; Hunt et al., 1991). Otherwise, the higher growth rate of bulls may be caused by the gradual increase of hormonal secretion throughout their growth period. It seems that anabolic hormones produced by the testicles cause this higher growth rate (Lee et al., 1990).

The weight of the principals cuts of the forequarter are shown in Table 5. No significant effect $(p>0.05)$ of the interaction sexual groups $v s$. concentrate levels was found for the weight and cuts dressing and concentrate levels, except for the chuck tender and heart. Thus, the results were discussed in relation to the sexual groups.

In the forequarter cuts, the shoulder and muscle quantities were similar, while the chuck tender, heart, neck, chuck, and shrink quantities were higher for bulls than for steers (Table 5). When expressed as a percentage, the secondary cuts of the hindquarter were not influenced ( $p>0.05$ ) by the sexual groups, except for dressing of the neck $(8.8 \%$ vs $6.8 \%)$ and chuck $(4.6 \%$ vs $3.6 \%)$ which higher for bulls than for steers.

In order to evaluate the differences between bulls and steers, especially in the forequarter cuts, it was verified that bulls produced $56 \%$ more meat of the neck and chuck, confirming the results reported by Seideman et al. (1982). This change in the primary cuts is related to the testosterone effect, which is responsible for the sexual dimorphism and characteristics of the male, and that depreciates certain aspects of the carcass and increases the percentage of the forequarter, as observed in this paper; this leads to an increased production of cuts with lower commercial value.

In relation to the hindquarter cuts (Table 6), differences $(\mathrm{p}<0.05)$ were found, such that bulls presented a higher weights for the tenderloin $(22.8 \%)$, knuckle $(14.8 \%)$, eye round $(28.3 \%)$ topside $(18.5 \%)$, flat $(17.1 \%)$, rump $(18.3 \%)$, and strip loin $(16.2 \%)$. For the other cuts of the forequarter and rump cover, no differences were observed $(\mathrm{p}>0.05)$. The higher values observed in the cuts weight were results of the higher carcass weights of bulls.

The secondary cuts of the forequarter (shoulder and chuck tender) and hindquarter (topside and flat) were influenced by the concentrated level of the diet (Tables 5 and 6). The shoulder, topside, and flat had a lower percentage dressing with the increase in the concentrate level. These results are different than those found by Gesualdi Jr et al. (2000), who did not find a difference in the cuts of crossbred steers Nellore vs Limousine with different concentrate levels. According to Berg and Butterfield (1966), animals present with similar deposits of muscle in forequarter and hindquarter cuts; thus, animals that presented with heavier forequarter cuts will also present with heavier hindquarter cuts. Thus, these small differences in the results may be attributed to the variation and positioning of those cuts in the carcasses.

\section{CONCLUSION}

Bulls produce heavier carcasses, and in the dissection of commercial cut also presented with higher dressing in the three cuts, there by resulting in a higher edible portion. Thus, more young bulls produced higher weights of 
Table 6. Dressing means and statistical comparison for the commercial cuts of the hindquarter according to the concentrate level and sexual groups

\begin{tabular}{|c|c|c|c|c|c|c|c|}
\hline \multirow{2}{*}{ Cuts } & \multicolumn{2}{|c|}{ Sexual groups } & \multicolumn{3}{|c|}{ Concentrate level (\%) } & \multicolumn{2}{|c|}{$\mathrm{p}<$ value } \\
\hline & Bull & Steer & 0.8 & 1.1 & 1.4 & SG & $\mathrm{CL}$ \\
\hline Tenderloin (kg) & 2.42 & 1.97 & 2.04 & 2.21 & 2.35 & $* * *$ & NS \\
\hline Rump cover (kg) & 1.98 & 1.75 & 1.70 & 1.89 & 2.01 & NS & NS \\
\hline Knuckle (kg) & 6.66 & 5.79 & 5.69 & 6.29 & 6.70 & $*$ & NS \\
\hline Eye round (kg) & 2.72 & 2.12 & 2.25 & 2.54 & 2.47 & $* * *$ & NS \\
\hline Topside (kg) & 8.89 & 7.51 & 8.06 & 8.27 & 8.27 & $* * *$ & NS \\
\hline Flat (kg) & 5.06 & 4.32 & 4.67 & 4.75 & 4.65 & $* *$ & NS \\
\hline Muscle (kg) & 5.58 & 5.04 & $5.00^{\mathrm{c}}$ & $5.74^{\mathrm{a}}$ & $5.19^{\mathrm{b}}$ & NS & $* *$ \\
\hline Rump (kg) & 5.62 & 4.75 & 4.86 & 5.69 & 5.02 & $*$ & NS \\
\hline Strip loin $(\mathrm{kg})$ & 9.03 & 7.77 & 7.71 & 8.72 & 8.77 & NS & NS \\
\hline Tenderloin (\%) & 1.84 & 1.79 & 1.80 & 1.74 & 1.91 & NS & NS \\
\hline Rump cover (\%) & 1.48 & 1.58 & 1.48 & 1.48 & 1.63 & NS & NS \\
\hline Knuckle (\%) & 5.01 & 5.23 & 5.01 & 4.93 & 5.42 & NS & NS \\
\hline Eye round (\%) & 2.03 & 1.91 & 1.96 & 1.97 & 1.99 & NS & NS \\
\hline Topside (\%) & 6.72 & 6.79 & $7.13^{\mathrm{a}}$ & $6.44^{\mathrm{c}}$ & $6.71^{\mathrm{b}}$ & NS & $* *$ \\
\hline Flat $(\%)$ & 3.80 & 3.97 & $4.14^{\mathrm{a}}$ & $3.76^{\mathrm{b}}$ & $3.75^{\mathrm{b}}$ & NS & $*$ \\
\hline Muscle (\%) & 4.23 & 4.24 & 4.29 & 4.34 & 4.09 & NS & NS \\
\hline Rump (\%) & 6.74 & 6.93 & 6.73 & 6.80 & 6.98 & NS & NS \\
\hline
\end{tabular}

NS, not significant.

Means followed by different letters in the same line are different. ${ }^{*} \mathrm{p}<0.05, * * \mathrm{p}<0.01, * * * \mathrm{p}<0.001$.

tenderloin, knuckle, topside, flat, eye round, rump, and strip loin. The termination of young bulls in feedlot is recommended, because these animals produce carcasses with higher amounts of edible portions and higher commercial dressing cuts, thereby allowing for a higher appreciation of the carcass. However, the increase of concentrate in the diet has no effect on these characteristics. Thus, low concentrate level could be used due to the lower cost of production for farmers.

\section{ACKNOWLEDGMENTS}

This project was supported by the Araucaria Foundation, funds of the state of PR, Brazil, and the Brazilian Council for Research and Technological Development (CNPq). The authors would like to thank Instituto de Pesquisa Agropecuária do Paraná (IAPAR, Ponta Grossa, PR, Brazil) for providing the facilities and animals.

\section{REFERENCES}

Albertí, P., B. Panea, C. Sañudo, J. L. Olleta, G. Ripoll, P. Ertbjerg, M. Christensen, S. Gigli, S. Failla, S. Concetti, J. F. Hocquette, R. Jailler, S. Rudel, G. Renand, G. R. Nute, R. I. Richardson, and J. L. Williams. 2008. Live weight, body size and carcass characteristics of young bulls of fifteen European breeds. Livest. Sci. 114:19-30.

ANUALPEC. 2014. Anuário da Pecuária Brasileira. 20th ed. Instituto FNP, São Paulo, SP, Brasil.

AOAC. 2005. Association Official Analytical Chemists. 18th ed.
Official Methods of Analysis, Gaitherburg, MD, USA.

Arboitte, M. Z., I. L. Brondani, J. Restle, L. S. Freitas, L. B. Pereira, and G. S. Cardoso. 2012. Carcass characteristics of small and medium-frame aberdeen angus young steers. Acta Sci. Anim. Sci. 34:49-56.

Aricetti, J. A., P. P. Rotta, R. M. Prado, D. Perotto, J. L. Moletta, M. Matsushita, and I. N. Prado. 2008. Carcass characteristics, chemical composition and fatty acid profile of Longissimus muscle of bulls and steers finished in a pasture system bulls and steers finished in pasture systems. Asian Australas. J. Anim. Sci. 21:1441-1448.

Berg, R. T. and R. M. Butterfield. 1966. Muscle: bone ratio and fat percentage as measures of beef carcass composition. Anim. Prod. 8:1-11.

Bretschneider, G. 2005. Effects of age and method of castration on performance and stress response of beef male cattle: A review. Livest. Prod. Sci. 97:89-100.

CIOMS/OMS. 1985. Council for International Organizations of Medical Services - International Guiding Principles for Biomedical Research Involving Animals. 1th ed. ERIC Clearinghouse, Geneva, Switzerland.

Field, R. A. 1971. Effect of castration on meat quality and quantity. J. Anim. Sci. 32:849-858.

Freitas, A. K., J. Restle, P. S. Pacheco, J. T. Padua, M. E. Lage, E. S. Miyagi, and G. F. R. Silva. 2008. Carcass characteristics of Nellore cattle kept intact or castrated at two ages, feedlot finished. Rev. Bras. Zootec. 37:1055-1062.

Gesualdi Jr, A., M. F. P., S. C. J. Valadares Filho, F. C. M. Coelho da Silva, C. M. Veloso, and P. R. Cecon. 2000. Concentrate levels in the diets of F1 Limousin $\times$ Nellore bulls: Carcass characteristics. Rev. Bras. Zootec. 29:1467-1473.

Hankins, O. G. and P. E. Howe. 1946. Estimation of the 
composition of beef carcasses and cuts. US Department of Agriculture, Technical bulletin USDA, Washington, USA. 926:1-20.

Henricks, D. M. 1991. Biochemistry and physiology of the gonadal hormones (Eds. P. T. Cupps and I. Animals). Reprod. Domest. Anim. No. 1. Academic Press, Inc., San Diego, CA, USA. pp. 81-118.

Hocquette, J.-F., R. Botreau, B. Picard, A. Jacquet, D. W. Pethick, and N. D. Scollan. 2012. Opportunities for predicting and manipulating beef quality. Meat Sci. 92:197-209.

Hunt, D. W., D. M. Henricks, G. C. Skelley, and L. W. Grimes. 1991. Use of trenbolone acetate and estradiol in intact and castrate male cattle: Effects on growth, serum hormones, and carcass characteristics. J. Anim. Sci. 69:2452-2462.

Kearl, L. C. 1982. Nutrient requirements of ruminants in developing countries. 1st ed. International Feedstuffs Institute, Utah Agricultural Experiment Station, Utah State University, Utah, UT, USA.

Knight, T. W., G. P. Cosgrove, A. F. Death, and C. B. Anderson. 2000. Effect of age of pre- and post-pubertal castration of bulls on growth rates and carcass quality. N.Z. J. Agric. Res. 43: 585-588.

Kuss, F., J. López, J. O. J. Barcellos, J. Restle, J. L. Moletta, and D. Perotto. 2009. Carcass characteristics of intact or castrated feedlot-finished males slaughtered at 16 or 26 months of age. Rev. Bras. Zootec. 38:515-522.

Lee, C. Y., D. M. Henricks, G. C. Skelley, and L. W. Grimes. 1990. Growth and hormonal response of intact and castrate male cattle to trenbolone acetate and estradiol. J. Anim. Sci. 68: 2682-2689.

Lunstra, D. D., J. J. Ford, and S. E. Echternkamp. 1978. Puberty in beef bulls: Hormone concentrations, growth, testicular development, sperm production and sexual aggressiveness in bulls of different breeds. J. Anim. Sci. 46:1054-1062.

Macedo, L. M., I. M. Prado, J. M. Prado, P. P. Rotta, R. M. Prado, N. E. Souza, and I. N. Prado. 2008. Chemical composition and fatty acids profile of five carcass cuts of crossbred heifers finished in feedlot. Semina: Ciências Agrárias 29:597-608.

Mach, N., A. Bach, C. E. Realini, M. Font i Furnols, A. Velarde, and M. Devant. 2009. Burdizzo pre-pubertal castration effects on performance, behaviour, carcass characteristics, and meat quality of Holstein bulls fed high-concentrate diets. Meat Sci. 81:329-334.

Maggioni, D., J. A. Marques, P. P. Rotta, D. Perotto, T. Ducatti, J. V. Visentainer, and I. N. Prado. 2010. Animal performance and meat quality of crossbred young bulls. Livest. Sci. 127:176182.

Mertens, D. R. 2002. Gravimetric determination of amylasetreated neutral detergent fiber in feeds with refluxing in beakers or crucibles: collaborative study. J. AOAC Int. 85: 1217-1240.
Missio, R. L., I. L. Brondani, J. Restle, J. H. Souza da Silva, M. F. Silveira, and V. S. Silva. 2009. Non-integrant components of the carcass from young bulls fed different concentrate levels. Rev. Bras. Zootec. 38:906-915.

Nelder, J. A. and R. W. M. Wedderburn. 1972. Generalized linear models. Journal of the Royal Statistical Society. Series A 135: 370-384.

Nerín, C., L. Tovar, D. Djenane, J. Camo, J. Salafranca, J. A. Beltrán, and P. Roncalés. 2006. Stabilization of beef meat by a new active packaging containing natural antioxidants. J. Agric. Food Chem. 54:7840-7846.

NRC. 2000. Nutrient Requirements of Beef Cattle. 7th rev. ed. Natl. Acad. Press, Washington, DC, USA.

Perotto, D., J. J. S. Abrahão, J. L. Moletta, M. C. Paula, and F. Kuss. 2009. Physical composition, primary cuts and meat cuts of carcasses from Zebu and Bos taurus $\times$ Bos indicus crossbred cattle. Rev. Bras. Zootec. 38:1712-1718.

Prado, R. M., I. N. Prado, J. A. Marques, P. P. Rotta, J. V. Visentainer, R. R. Silva, and N. E. Souza. 2009. Meat quality of the Longissimus muscle of bulls and steers ( $1 / 2$ Nellore $v$ s. $1 / 2$ Simmental) finished in feedlot. J. Anim. Feed Sci. 18:221-230.

Restle, J., D. C. Alves Filho, C. Faturi, J. R. P. Rosa, L. L. Pascoal, R. A. C. Bernardes, and F. Kuss. 2000. Desempenho na fase de crescimento de machos bovinos inteiros ou castrados de diferentes grupos genéticos. Rev. Bras. Zootec. 29:1036-1043.

Restle, J., F. N. Vaz, A. R. B. Quadros, and L. Müller. 1999. Carcass and meat characteristics from steers of different of Hereford $\times$ Nellore genotypes. Rev. Bras. Zootec. 28: 12451251.

Rotta, P. P., I. N. Prado, R. M. Prado, J. L. Moletta, R. R. Silva, and D. Perotto. 2009a. Carcass characteristics and chemical composition of the Longissimus muscle of Nellore, Caracu and Holstein-Friesian bulls finished in a feedlot. Asian Australas. J. Anim. Sci. 22:598-604.

Rotta, P. P., R. M. Prado, I. N. Prado, M. V. Valero, J. V. Visentainer, and R. R. Silva. 2009b. The effects of genetic groups, nutrition, finishing systems and gender of Brazilian cattle on carcass characteristics and beef composition and appearance: A review. Asian Australas. J. Anim. Sci. 22:17181734.

SAS. 2004. SAS/STAT User Guide, Version 9.1.2. SAS Institute Inc, Cary, NC, USA.

Seideman, S. C., H. R. Cross, R. R. Oltjen, and B. D. Schanbacher. 1982. Utilization of the intact male for red meat production: a review. J. Anim. Sci. 55:826-840.

Shimada, K., Y. Sakuma, J. Wakamatsu, M. Fukushima, M. Sekikawa, K. Kuchida, and M. Mikami. 2004. Species and muscle differences in L-carnitine levels in skeletal muscles based on a new simple assay. Meat Sci. 68:357-362.

Sniffen, C. J., J. D. O'Connor, P. J. Van Soest, D. G. Fox, and J. B. Russell. 1992. A net carbohydrate and protein system for evaluating cattle diets: II. Carbohydrate and protein availability. J. Anim. Sci. 70:3562-3577. 